\title{
Questões provisórias sobre literatura e tecnologia: um diálogo com Roger Chartier
}

\author{
Ana Elisa Ribeiro ${ }^{1}$
}

Quero começar com José Saramago, na afirmação do protagonista da História do Cerco de Lisboa, edição brasileira de 1989, que me custou prosseguir na leitura, uma vez que cada parágrafo me exigia renovada reflexão:

Agora me ocorre que tanto o Eça como o Balzac se sentiriam os mais felizes dos homens, nos tempos de hoje, diante de um computador, interpolando, transpondo, recorrendo linhas, trocando capítulos, e nós, leitores, nunca saberíamos por que caminhos eles andaram e se perderam antes de alcançarem a definitiva forma, se existe tal coisa (Saramago, 1989, p. 13).

O trecho, que surgia logo nas primeiras páginas do calhamaço que tem como protagonista um revisor de textos, foi capaz de me deter até a atualidade (e foi lido muitos anos atrás). Nessas linhas, Saramago consegue fazer confluírem questões relacionadas à produção editorial contemporânea, mais especificamente no campo literário, aventando possibilidades, no entanto improváveis - por citar autores mortos -, ligadas aos modos de escrever, em sua face mais íntima e mais particularmente técnica. Está em foco o momento do escritor, isto é, seus modos de produzir textos, seu equipamento e suas artimanhas de edição (escrita, reescrita, revisão, interpolações, transposições e recorrências). Ainda: a maneira como o escritor maneja o texto na composição de uma peça literária.

Do ponto de vista de quem produz o texto, sem deixar de antes ter sido leitor de outros, a grande e suposta felicidade seria poder manipular com mais facilidade as frases, os parágrafos e as palavras, inclusive tornando difícil, se não impossível, a revelação posterior desses caminhos de edição textual nos quais o autor também se encontra e se perde (e não apenas o leitor). Não se sabe se a tal felicidade seria, então, obter um equipamento que propiciasse o manejo mais fluido do texto ou que permitisse o resguardo dos segredos da

\footnotetext{
${ }^{1}$ Doutora em estudos linguísticos e professora do Departamento de Linguagem e Tecnologia (Deltec) do Centro Federal de Educação Tecnológica de Minas Gerais (Cefet/MG), Belo Horizonte, MG, Brasil. E-mail: anadigital@gmail.com
} 
produção. É importante, no entanto, lembrar que quem diz isso é um protagonista revisor de textos, isto é, uma figura que atua sobre o texto do autor, sem sê-lo, ou ao menos sem obter as créditos de coautor. ${ }^{2}$

No entanto, não resta esquecido o leitor. Embora, como supõe o narrador do Cerco, Balzac ou Eça pudessem gostar de editar nos editores de texto eletrônicos, ao modo dos escritores de hoje, em massa, não poderiam, talvez, registrar seus avanços e recuos na escrita de suas obras. Eis uma questão que incomoda a crítica genética, que tratou, de maneira valiosa, das origens e das metamorfoses do texto literário com base em, por exemplo, originais rasurados, rabiscados e reescritos pelo próprio autor, principalmente. Tal registro provavelmente terá sido apagado dos livros atuais, exceto para o caso de algum autor de antemão preocupado com a escavação de sua própria história.

Também não ficou esquecido o texto, em sua inalcançável "definitiva forma". "Se existe tal coisa" é a expressão modalizadora necessária quando se considera, adequadamente, que dificilmente um escritor fica satisfeito com sua produção ao ponto de chamá-la "pronta", sem alguma sombra de dúvida, e, de outro lado, todo leitor lerá de modo criativo e preenchedor uma obra literária, quanto mais leitor for.

Se não existe o texto "pronto", pode-se, talvez, falar no texto "final", colocando-se como critério preponderante dessa adjetivação uma data, um prazo, um deadline que faça o escritor parar de escrever, não necessariamente quando considera ter escrito tudo o que queria ou como gostaria. Ao leitor caberá ler talvez numa espécie de "coautoria", como defendem alguns. ${ }^{3}$ A meu ver, cabe pensar em um diálogo no encontro entre texto e leitor, muita vez à revelia do autor, que fez, no entanto, sua proposta, não podendo ser desconsiderado nessa "fusão" 4 - em especial, no caso da literatura.

É este mesmo historiador que vem afirmar, dando ênfase à atividade da leitura, que,

das análises que acompanham a atividade leitora em seus rodeios, percursos através da página, metamorfoses e

\footnotetext{
${ }^{2}$ Luciana Salazar Salgado tem se dedicado a uma discussão mais contemporânea sobre a autoria, inclusive do ponto de vista da revisão textual. Ver, por exemplo, Salgado (2011; 2013). É provável que se tenha de passar pelas discussões sobre autoria mais conhecidas entre nossas referências, tais como Foucault e Barthes, nos quais não me deterei aqui (Foucault, 2002; Barthes, 1984).

${ }^{3}$ Talvez se localize aqui a proposta de "lautor", bem escrita por Bellei (2005).

${ }^{4}$ Na palavra de Michel de Certeau (2008).
} 
anamorfoses do texto pelo olho que viaja, voos imaginários ou meditativos a partir de algumas palavras, transposições de espaços sobre as superfícies militarmente dispostas do escrito, danças efêmeras, depreende-se ao menos em um primeiro enfoque que não se poderia conservar a rígida separação da leitura e do texto legível (livro, imagem, etc.). Quer se trate do jornal ou de Proust, o texto só tem sentido graças a seus leitores; muda com eles; ordena-se conforme códigos de percepção que lhe escapam (Certeau, 2008, p. 266).

Neste trabalho, levando-se em consideração a escrita literária desde sua origem, nas mãos do escritor, até sua misteriosa circulação - por meio de livros ou não -, pretende-se abordar, como sói ser, de maneira não conclusiva, a relação entre tecnologias digitais e leitura, mais aproximadamente a literária, mas do ponto de vista da produção editorial, isto é, não vou tratar aqui de aspectos cognitivos ou de valor literário propriamente, mas de questões que podem fazer pensar a produção editorial no campo literário, na contemporaneidade, em um cenário em que as tecnologias digitais de ler e escrever já podem ser consideradas incorporadas pela sociedade, mesmo que ainda haja problemas relacionados à alfabetização, à educação, ao letramento literário e mesmo ao acesso e à conectividade tecnológica.

A discussão posta partirá de um intenso diálogo com a história das práticas da leitura, especialmente em Roger Chartier, mas também em outros autores. $\mathrm{O}$ historiador francês tem diversas obras traduzidas ao português no Brasil, motivo pelo qual tem influenciado muito um modo de pensar o livro e sua circulação entre os interessados nos estudos da edição e da produção editorial. Penso ser fundamental rever certas propostas de Chartier à luz do que vem acontecendo muito contemporaneamente, em uma tentativa de organizar argumentos esparsos em livros de sua autoria e discutir questões levantadas, à luz de alguns exemplos no Brasil, especialmente o de pequenas editoras e produções editoriais.

\section{Da leitura e da tecnologia, com Roger Chartier}

Uma pergunta, formulada por Roger Chartier, talvez me guie no empreendimento deste texto: "Como pensar a leitura diante de uma oferta textual que a técnica eletrônica multiplica mais ainda do que a 
invenção da imprensa?" (Chartier, 2002, p. 21). Essa formulação, datada, tem como eixo a comparação entre tecnologias de impressão e difusão muito distantes no tempo e no espaço, tais como a prensa tipográfica e o computador. A questão posta focaliza a "oferta textual" muito ampliada que temos hoje, mas que a sociedade da Idade Média também teve a impressão de conhecer. Parece haver qualquer incongruência ou assimetria incômoda entre as questões de leitura e de circulação de textos. ${ }^{5}$

Quanto à "oferta textual", conforme o tom da pergunta e a quantidade de pensadores preocupados com ela, parece um problema que haja textos demais no mundo - ou leitores de menos. Livros demais, como exclamou Gabriel Zaid (2004), como uma enxurrada de produtos que se perdem em um tortuoso caminho entre a edição e a leitura. Mais textos do que leitores? Leitores precários? ${ }^{6}$ Leitura rarefeita? ${ }^{7}$ Mas como compreender a profusão dos textos na internet, nas redes sociais e mesmo entre as pessoas em seu cotidiano? Que discurso - negativo sustenta a ideia de que quase não lemos (especialmente no Brasil)? ${ }^{8}$ Que outro discurso pode explicar a quantidade de livros lançados a todo momento, inclusive por editoras pequenas, que produzem materiais que nada ficam a dever aos grandes grupos multinacionais? ${ }^{9}$

Chartier ainda reivindica para a história um olhar mais "sensato", defendendo uma posição de equilíbrio sobre os objetos que aqui nos interessam, quais sejam: a leitura e a circulação dos textos. Segundo ele, "entre as lamentações nostálgicas e os entusiasmos ingênuos suscitados pelas novas tecnologias, a perspectiva histórica pode traçar um caminho mais sensato, por ser mais bem informado" (Chartier, 2002, p. 9). Uma pequena lista do que o historiador chama de "principais mutações que a entrada na era do texto e do mundo digitais impõe às relações que mantemos com a cultura escrita" pode

\footnotetext{
${ }^{5}$ Talvez seja interessante lembrar que enquanto a prensa era, sim, um equipamento dedicado à impressão (de folhetos, libelos, livros, livretos, etc.), o computador (e seus periféricos) não é, mas apenas pode ser. O que também ocorre aos materiais de ler, como o próprio livro e alguns dispositivos móveis eletrônicos atuais, com telas de todo tipo.

${ }^{6}$ Do título do livro de Bahloul (2002), Lecturas precarias.

${ }^{7}$ Do título do livro de Lajolo e Zilberman, Regina (2002), A leitura rarefeita.

${ }^{8}$ Ver, por exemplo, para uma ampla discussão, com dados sobre isso, Abreu (2000).

9 Venho trabalhando no registro dessas iniciativas: Ribeiro (2009a; 2013; 2013a; no prelo) e Ribeiro; Guimarães (2014). Guimarães (2013) tem um trabalho primoroso sobre pequenas editoras.
} 
ser, então, composta: a) transformações das práticas de leitura; b) novas modalidades de publicação; e c) redefinição da identidade e da propriedade das obras (Chartier, 2002, p. 7).

$\mathrm{Na}$ mesma obra, Chartier elenca três rupturas na "ordem do discurso", causadas pelo "mundo eletrônico", representado pelo computador: a) propõe uma nova técnica de difusão da escrita; b) incita uma nova relação com os textos; e c) impõe-lhes uma nova forma de inscrição (Chartier, 2002, p. 23-24). Em uma proclamação um tanto radical, o historiador afirma:

A originalidade e a importância da revolução digital apoiam-se no fato de obrigar o leitor contemporâneo a abandonar todas as heranças que o plasmaram, já que o mundo eletrônico não mais utiliza a imprensa, ignora o "livro unitário" e está alheio à materialidade do códex (Chartier, 2002, p. 23-24).

O que qualifiquei como "exagero" diz respeito a uma pretensa obrigatoriedade que, de fato, não existe (ainda?). O referido "abandono" das heranças da cultura escrita ainda não ocorreu, nem mesmo como elemento estético de muitas páginas web, simulacros de páginas de papel. Muito embora o leitor de telas possa estar, naquele momento, alheio à imprensa como técnica de produção, assim como ao livro unitário ou à materialidade de papel (pois está em contato com outra, também retangular), ele, por enquanto, transita entre elas, não sendo necessariamente obrigado a escolher. Insisto, portanto, no caráter múltiplo das práticas de leitura atuais, ainda muito herdeiras das práticas do impresso e, talvez, sempre assim. Os números atuais sobre produção e consumo de e-books, por exemplo, no Brasil, ainda não permitem considerar esta uma questão de substituição, obrigatoriedade ou "abandono" de heranças do impresso. ${ }^{10}$

De novo, seriam, para Chartier, três revoluções: i) da modalidade técnica da produção do escrito; ii) da percepção das entidades textuais; e iii) das estruturas e das formas mais fundamentais dos suportes da cultura escrita (Chartier, 2002, p. 24)

\footnotetext{
${ }^{10}$ Em debate recente no Festival Literário de Araxá (FliAraxá), Minas Gerais, Fábio Cesnik, da Cesnik, Quintino \& Salinas Advogados, divulgava números recentes da indústria editorial digital. As informações indicam ainda um consumo muito baixo de livros eletrônicos entre os brasileiros (Cesnik, 2015).
} 
A insistência nessas mudanças aparece, antes, na obra de 1998, em que o historiador afirma que "a revolução do nosso presente é mais importante do que a de Gutenberg", uma vez que "ela não somente modifica a técnica de reprodução do texto, mas também as estruturas e as próprias formas do suporte que o comunica aos seus leitores" (Chartier, 1998, p. 98). Mais adiante, ele afirma que, "com a tela, substituta do códex, a transformação é mais radical, pois são os modos de organização, de estruturação, de consulta ao suporte do escrito que se modificam" (Chartier, 1998, p. 98, grifo nosso). A despeito de haver mesmo uma profunda diferença estrutural (mais ligada a modos de produção e de circulação, e nem tanto estética e de organização) entre produtos editoriais impressos e digitais, a substituição do códex pela tela não chega a ser sequer uma vaga ameaça.

As mudanças percebidas são, no entanto, relativizadas por afirmações que tocam em pontos importantes, afinal, "as telas do presente não ignoram a cultura escrita, mas a transmitem" (Chartier, 2002 , p. 30). Como venho alertando, ${ }^{11}$ a "cultura digital" não está em oposição à "cultura escrita". Isso tem mais a ver com fusões e sobreposições transparentes do que com concorrências. Talvez a "cultura impressa", sim, esteja sendo "incomodada" pela "cultura digital", mas muito mais em um sentido de interinfluência do que, propriamente, de exclusividade. Em outra formulação de Chartier (2002, p. 8), "as novas técnicas não apagam nem brutal nem totalmente os antigos usos", isto é, "a era do texto eletrônico será ainda, e certamente por muito tempo, uma era do manuscrito e do impresso".

A patente dificuldade da indústria editorial em criar produtos genuinamente digitais análogos a livros tem forte relação com uma dificuldade de abandonar modelos impressos de leitura. Por sua vez, a indústria do impresso estuda formas simpáticas à estética do digital como forma de mudar seus produtos. ${ }^{12}$ Assim:

São ainda grandes as defasagens entre a presença da revolução eletrônica nos discursos (inclusive neste...) e a realidade das práticas de leituras que permanecem maciçamente ligadas aos objetos impressos e só exploram muito parcialmente as possibilidades

\footnotetext{
${ }^{11}$ Como fiz em Ribeiro (2013b).

${ }^{12}$ Há uma discussão sobre o tema, com exemplos, em Albarrán e Ribeiro (2013).
} 
oferecidas pelo digital. Devemos ser bastante lúcidos para não tomarmos o virtual por um real já presente (Chartier, 2002, p. 113).

Segundo Chartier (2002, p. 116), em outras palavras, as práticas atuais de edição "muitas vezes se contentam em pôr na Web os textos brutos que não foram nem pensados, em relação à nova forma de suas transmissões, nem submetidos a nenhum trabalho de correção ou de edição". Penso que seja o caso mais visualizável do jornalismo, por exemplo, que vem se esforçando para criar produtos que melhor se apropriem de novas possibilidades de escrita e de leitura.

Novamente, Chartier lembra que (2002, p. 112):

a longa história da leitura mostra com firmeza que as mutações na ordem das práticas são geralmente mais lentas do que as revoluções das técnicas e sempre em defasagem em relação a elas. Da invenção da imprensa não decorreram imediatamente novas maneiras de ler. Do mesmo modo, as categorias intelectuais que associamos ao mundo dos textos perdurarão diante das novas formas do livro.

E vem a formulação de mais uma trinca sobre a "revolução do texto eletrônico": i) na técnica de produção dos textos; ii) do suporte do escrito; e iii) das práticas de leitura (Chartier, 2002, p. 113).

Fala-se, então, de um circuito em que estão envolvidos novos modos de produção, disseminação e apropriação dos textos, ou seja, novas maneiras de escrever, de publicar e de ler.

Para o autor, "é agora um único aparelho, o computador, que faz surgir diante do leitor os diversos tipos de textos tradicionalmente distribuídos entre objetos diferentes" (2002, p. 22-23), o que alteraria o ordenamento que então conhecemos na cultura impressa. Alteraria e confundiria, em alguma medida, pois

todos os textos, sejam eles de qualquer gênero, são lidos em um mesmo suporte (a tela do computador) e nas formas (geralmente as que são decididas pelo leitor). Cria-se assim uma continuidade que não mais diferencia os diversos discursos a partir de sua própria materialidade (Chartier, 2002, p. 22-23).

A leitura parece sempre entendida em suas relações com a tecnologia e como prática social nos textos de Chartier. E se esse enquadramento não é abandonado, ele justifica uma visão do ato de ler como sempre móvel e efêmero ou transitório e criativo. É assim que 
Chartier (1998, p. 7) afirma: “A leitura é, por definição, rebelde e vadia", em uma formulação quase literária.

Na mesma obra, o autor explicita que "a revolução do texto eletrônico será ela também uma revolução da leitura" (1998, p. 101). Para ele, a representação eletrônica dos textos traz uma série inescapável de mudanças que precisam ser percebidas e consideradas:

Ela substitui a materialidade do livro pela imaterialidade de textos sem lugar específico; às relações de contiguidade estabelecidas no objeto impresso ela opõe a livre composição de fragmentos indefinidamente manipuláveis; à captura imediata da totalidade da obra, tornada visível pelo objeto que a contém, ela faz suceder a navegação de longo curso entre arquipélagos textuais sem margens nem limites. Essas mutações comandam, inevitavelmente, imperativamente, novas maneiras de ler, novas relações com a escrita, novas técnicas intelectuais. Se as revoluções da leitura precedentes fizeram-se sem mudar as estruturas fundamentais do livro, não é isso que irá acontecer em nosso mundo contemporâneo. A revolução iniciada é, antes de tudo, uma revolução dos suportes e formas que transmitem o escrito. Nisso, ela tem um único precedente no mundo ocidental: a substituição do volumen pelo códex - do livro em forma de rolo pelo livro composto por cadernos reunidos -, nos primeiros séculos da era cristã (Chartier, 1998, p. 101).

Considera, no entanto, muito aproximado dos textos literários, que:

As obras - mesmo as maiores, ou, sobretudo, as maiores - não têm sentido estático, universal, fixo. Elas estão investidas de significações plurais e móveis, que se constroem no encontro de uma proposição com uma recepção. Os sentidos atribuídos às suas formas e aos seus motivos dependem das competências ou das expectativas dos diferentes públicos que delas as apropriam (Chartier, 1998, p. 9).

No entanto, talvez a tese mais importante de Chartier seja a que vai formulada em seu livro de 1998 e tem sido reiterada em diversos outros, com menos ou mais palavras. Do ponto de vista da leitura e de suas práticas (incluindo aspectos cognitivos e gestos), este parece o cerne da questão que nos anima e nos faz viver, com tanta fascinação, este momento de movimentação na cultura escrita:

deve-se lembrar que não há texto fora do suporte que o dá a ler (ou a ouvir), e sublinhar o fato de que não existe a compreensão de um texto, qualquer que ele seja, que não dependa das formas através das 
quais ele atinge o seu leitor. Daí a distinção necessária entre dois conjuntos de dispositivos: os que destacam estratégias textuais e intenções do autor, e os que resultam de decisões de editores ou de limitações impostas por oficinas impressoras (Chartier, 1998, p. 17).

Ou:

Os textos não existem fora dos suportes materiais (sejam eles quais forem) de que são os veículos. Contra a abstração dos textos, é preciso lembrar que as formas que permitem sua leitura, sua audição ou sua visão participam profundamente da construção de seus significados. $\mathrm{O}$ "mesmo" texto, fixado em letras, não é o "mesmo" caso mudem os dispositivos de sua escrita e de sua comunicação (Chartier, 2002, p. 61-62).

A forte relação, defendida pelo autor, entre forma e produção de sentidos (leitura) parece ainda pouco considerada em abordagens exclusivamente linguísticas ou literárias que promovem o que se chamou aqui de "abstração dos textos", isto é, tratar a obra despida de seus elementos materiais. ${ }^{13}$

Para tornar tudo ainda mais complexo, Chartier afirma, em tom de alerta, sobre essa espécie de "transfusão" ou "transposição". ${ }^{14}$ Segundo o autor,

a possível transferência do patrimônio escrito de um suporte ao outro, do códex para a tela, inaugura imensas possibilidades, mas será também uma violência contra os textos, assim separados de forma que contribuíram para construir as suas significações históricas. Supondo que, num futuro mais ou menos próximo, as obras de nossa tradição não sejam mais comunicadas ou decifradas a não ser através de uma representação eletrônica, será grande o risco de ver perdida a inteligibilidade de uma cultura textual ou um antigo elo, essencial, a ligar o próprio conceito de texto a uma forma particular de livro: o códex (Chartier, 1998, p. 106-105).

A "violência" é, portanto, dar a ler textos descuidadamente transpostos de um meio a outro, algo que em muitos casos já ocorre. Porém, é necessário experimentar, convocar os textos a serem retextualizados (como foram o teatro e a literatura ao cinema, por

\footnotetext{
${ }^{13}$ Há um interessante texto sobre isso em Van Leeuwen (2004).

${ }^{14}$ Como discuti em Ribeiro (2009a).
} 
exemplo), até que se produzam, de fato, textos feitos genuinamente para ambientes digitais, isto é, com as possibilidades digitais em seu DNA.

É fundamental lembrar, com Chartier (2001, p. 108-109), que as tecnologias digitais ampliam as possibilidades de multissemiose.

$\mathrm{O}$ hipertexto e a hiperleitura que ele permite e produz transformam as relações possíveis entre as imagens, os sons e os textos associados de maneira não linear, mediante conexões eletrônicas, assim como as ligações realizadas entre os textos fluidos em seus contornos e em número virtualmente ilimitado. Nesse mundo textual sem fronteiras, a noção essencial torna-se a do elo pensado como a operação que relaciona as unidades textuais recortadas para a leitura.

Nas telas, texto, imagem, som, movimento podem ser orquestrados na composição de uma peça, em muitos gêneros textuais. Há, portanto, a consideração de uma diferença nas modulações do texto na tela e no impresso que provoca novos modos de ler ou, ao menos, modos diferentes, como prefiro pensar. Se as modulações do impresso permitem e propiciam a orquestração de algumas linguagens (visual e verbal, em sua diversidade), as modulações dos textos em ambientes digitais são outras, além de texto e imagem, permitindo som, imagem em movimento, etc. Essa seria, então, uma nova forma de ler, considerando-se o livro feito, por exemplo, para a leitura em tablets ou e-readers.

Essa breve revisão de alguns textos de Roger Chartier quer apresentar um diálogo sobre questões da leitura e da circulação dos textos nos dias que correm, já mais de década depois das considerações que o historiador teceu muito oportunamente.

\section{Organizando as tríplices propostas para uma quase conclusão}

Conforme apontei, Chartier (1998; 2001; 2002) defende algumas teses sobre a leitura e a circulação de livros, tocando sempre em questões tecnológicas, isto é, ligadas às mídias e às materialidades disponíveis para a inscrição dos textos. Com isso, o historiador propõe trincas de elementos que, para ele, resumem tipos de revoluções na história da escrita e da leitura, mais proximamente esta que vivemos hoje e que já ocorre pelo menos desde a invenção do computador em meados do século XX.

Atrevo-me a reorganizar as propostas tríplices de Chartier, esquematizando a seguinte proposta de visualização, que funda ou 
agrupa critérios ou temas. Segundo o autor, estamos em contato com: a) mudanças na cultura escrita provocadas pela chegada de mídias digitais; e b) rupturas com a cultura do impresso em decorrência da existência do que ele chama de "texto eletrônico". Isso acarreta mudanças na leitura, nos modos de publicação, nas formas dos objetos de ler e na circulação desses objetos (o que nos traz de volta à leitura), isto é, há intensa movimentação em todo o cenário em que é fundamental se considerar um sistema, um ciclo.

Veja-se então o diagrama proposto e, em seguida, alguns comentários com base nos quais viso complementar alguns pontos dessa discussão, incluindo-se a escolha de alguns termos, como movimento, mudança e transição:

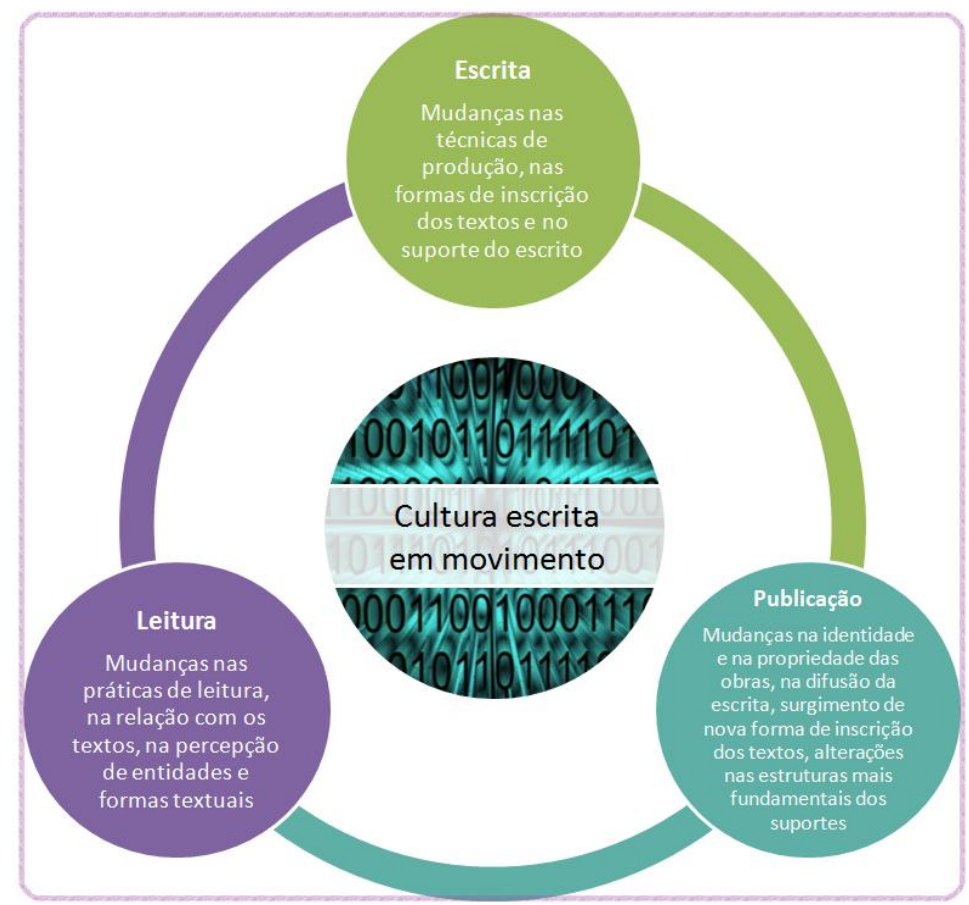

Figura 1 - Movimentos da cultura escrita, segundo Roger Chartier Fonte: Chartier (2002). Elaboração da autora. 


\section{Das razões pelas quais quero evitar os termos transição ou mudança}

Vou escolher o termo movimento para fazer as relações que penso serem mais adequadas e sensatas entre as culturas impressa e digital no âmbito da cultura escrita. Movimento me dá, então, uma noção que considero mais interessante do que outras, tendo em vista que não traz, necessariamente, um sentido de progressão (avanço/recuo, frente/trás, vantagem/desvantagem, maior/menor, evolução/involução, etc.). Melhor: creio trazer certa noção de atividade e de interação que interessa mais à análise do campo da edição e de sua história (é, por fim, do que tratamos quando falamos em leitura e escrita). O movimento traz, afinal, a noção de "coisa viva" e respirante que, de fato, a edição tem, pois está ligada às nossas mais duradouras práticas sociais.

O gráfico proposto linhas acima buscou representar essa noção. É fundamental que se construa uma representação das questões da edição, da leitura e da tecnologia como relações que se retroalimentam. Um novo suporte de leitura traz propostas de movimento para o próprio ato de ler; os movimentos do leitor ao ler propõem algo aos processos de edição, uma vez que uns aprendem com os outros, isto é, as práticas da leitura dizem aos editores como melhor formatar projetos. Se isso já ocorria em tempos remotos, hoje ocorre com mais rapidez.

Transição e mudança, sim, podem carregar a ideia de que algo passa de um estágio a outro, acarretando o sentido, que considero errôneo, de substituição, que é, finalmente, a discussão improfícua que temos há décadas (o fim disto e daquilo, ideias evolutivas sobre mídias etc.). Como sempre preferi um paradigma sistêmico, ecológico, evito termos que possam sustentar uma compreensão evolutiva ou concorrente entre as culturas do escrito. Admito, no entanto, que talvez possa ter incorrido no que considero equívoco em textos passados, mas terei tentado não incorrer.

É importante reiterar que Chartier nos lembra de que o códex substituiu o rolo (embora levasse tempo para fazê-lo), o que considera maior revolução (nas formas e nas tecnologias do livro) do que a invenção da prensa. No entanto, as tecnologias digitais vêm, para ele, promovendo revolução de força semelhante àquela, tendo em vista que, de novo, há alterações substanciais justo nas estruturas do livro, com a chegada de objetos de ler outros, completamente diferentes do que 
conhecíamos. Esse tipo de movimento é tão relevante - para o negócio do livro e para as práticas da leitura - que na atualidade há intensa discussão sobre impostos e alíquotas fortemente relacionadas a um conceito do que seja "livro". ${ }^{15}$ A despeito do reconhecimento de que há novos objetos em produção com esse mesmo nome, é importante considerar que a leitura vem sendo fomentada em todos eles.

\section{Movimentos na escrita}

Conforme aponta Chartier, esse tipo de movimento tem relação com as práticas mesmas do escritor, isto é, o abandono do manuscrito ou do datilografado em favor de uma produção digital já desde a origem. A escrita inicia-se nos arquivos virtuais, nos computadores, e processos de edição de textos, sejam os feitos pelo próprio autor ou aqueles executados por preparadores, leitores técnicos ou mesmo revisores, passam a ter lugar nesse ambiente, o que apaga os vestígios da criação literária, por exemplo. A citação de Saramago com que abro este artigo toca justamente neste ponto: o das práticas da produção textual por meio de editores eletrônicos.

Complementarmente, o escritor passa a dispor de espaços e ferramentas que podem ajudar a escoar seus textos de forma independente de editores e gráficas. Optando por um blog ou por vídeos, colunas em sites e mesmo redes sociais, livros fechados como PDFs ou ePubs, isto é, com grande variação nos resultados, passam a circular diretamente com os leitores. Essa, portanto, não é exatamente uma mudança, pois espaços de publicação digitais independentes convivem com a possibilidade da edição por meio de editoras de livros.

\section{Movimentos na publicação}

Estes movimentos, em grande medida, hoje se confundem com os movimentos da escrita, posto que o escritor pode operar os elementos da edição de sua obra até a sua distribuição. No entanto, é exagero -

\footnotetext{
${ }^{15}$ A França foi questionada pela União Europeia por ter alterado impostos em favor do livro eletrônico. Ver mais na campanha That is not a Book, em <http://unlivreestunlivre.eu/> e notícia em <http://www.publishnews.com.br/telas/noticias/detalhes.aspx?id=80889>. A Itália foi mais além: alterou sua definição de livro. O critério é o objeto, qualquer que seja ele, ter um ISBN. Vejase notícia em <http://www.publishnews.com.br/telas/noticias/detalhes.aspx?id=80775>.
} 
senão um equívoco - dizer que isso ocorre em substituição à edição tradicional. $\mathrm{O}$ valor literário ou editorial relacionado às obras ainda encontra seus mecanismos de existência e os recria ou reposiciona.

Em trabalho anterior (Ribeiro, 2011), mostrei como a publicação de livros que vieram de blogs ainda carregava, no discurso de autores e da mídia, um valor diferente - mais prestigioso - do que a publicação exclusivamente digital. Há, portanto, uma concatenação entre mídias, um diálogo e uma relação entre elas, que faz com que a publicação no blog tenha um efeito e uma função que se diferencia da função e do efeito do livro, valendo, portanto, ter os dois.

É facultado ao autor produzir sua própria obra, graficamente, ao menos desde as máquinas de mimeografar, como fizeram muitos poetas a partir de meados do século XX. No entanto, etapas como o design, a impressão e a distribuição ainda são nós da produção editorial independente.

As mídias digitais alteram essa relação se considerarmos que: i) o texto passa a ser produzido em computador; ii) o texto pode ser diagramado e publicado ainda se utilizando o computador; e iii) a distribuição por meio de arquivos digitais evita uma etapa de deslocamento físico da obra, dispensando uma logística demorada e onerosa. No entanto, esse ainda é um movimento que parece não satisfazer completamente as ambições do escritor, que mantém, em grande parte, seu desejo de obter um livro impresso que possa seguir uma trilha analógica e com a materialidade que a cultura escrita já conhece há mais tempo: a do impresso.

Há atualmente belos projetos de publicação de livros digitais que, no entanto, não substituem a produção de livros impressos, frequentemente dos mesmos autores. É exemplo o projeto Formas Breves, do e-Galáxia, coordenado pelo escritor paranaense Carlos Henrique Schroeder, que publica e-books de contos de escritores contemporâneos em vias de legitimação e consagração. ${ }^{16}$

Os movimentos na forma do suporte, isto é, a passagem do rolo ao códex, como lembra Chartier, comparando-a ao movimento atual do códex impresso aos formatos legíveis em displays (telas, mesmo que ainda imitem o códex), trazem alterações para as equipes de produção editorial (que passam a contar com designers web e programadores), para

\footnotetext{
${ }^{16}$ Vale a pena ver o belíssimo projeto em: 〈http://blog.e-galaxia.com.br/formas-breves/>
} 
elementos ligados ao hardware (questões de compatibilidade e obsolescência que não cabiam antes) e para as formas de circulação dos textos, incluindo-se os modelos de negócio e financiamento das editoras.

A apropriação do texto, sua difusão, os direitos autorais, o controle de suas cópias, sua visibilidade, seus modos de acesso tornam-se questões relevantes para todos os atores sociais envolvidos no mundo da leitura e da escrita. As práticas do leitor são afetadas desde sua decisão de adquirir um livro em sua versão impressa ou digital até suas "sensações" ao lidar com determinados aspectos da leitura, tais como este, em um livro digital, de contornos completamente novos na história dos suportes de ler:

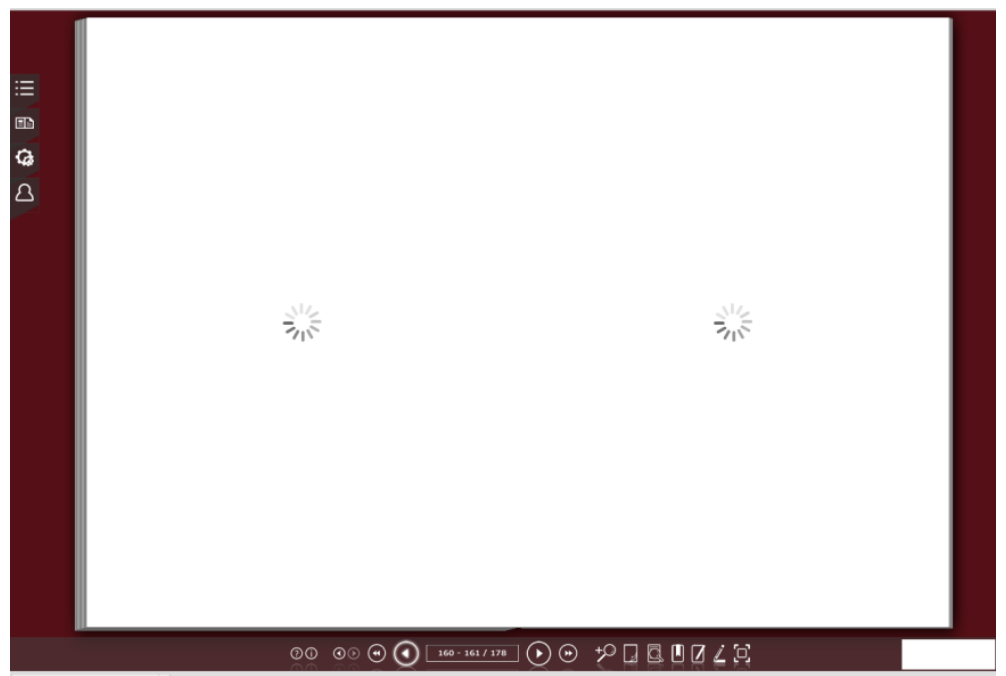

Figura 2 - Printscreen de tela mostrando o carregamento da página em livro digital acadêmico Elaboração da autora.

Há ainda questões de difusão e distribuição completamente novas. Para Chartier (1998, p. 282):

O meio eletrônico também permite a criação de um espaço inigualável para promoção do livro, onde se multiplicam grupos de discussão de bibliófilos, bibliotecários, editores, autores, colecionadores, pontos de vendas on-line de editoras e livrarias, 
estimulando a criação de novos públicos leitores e permitindo uma interação inédita entre autores, editores, leitores e bibliotecários.

E, de fato, isso vem ocorrendo, bastando pensar em livrarias como a Amazon ou em lojas com espaços físicos e virtuais, como a Cultura, no Brasil, com expressivas vendas pela web; sebos e seus coletivos, como a Estante Virtual; ${ }^{17}$ infinitos fóruns e redes para discussão do tema da produção editorial, em aspectos menos ou mais amplos; redes de leitores, como o Skoob;18 além de fan fictions criadas por fãs para discutir, traduzir e interferir em obras; e da discussão sobre bibliotecas virtuais ou digitalizadas. ${ }^{19}$

O campo da literatura vive todas essas pressões e movimentações sem se furtar à sua índole de espaço de experimentação e de pesquisa de novos modos de dizer. E-books que se pretendem multimídia, narrativas que se apropriam do hipertexto, aspectos tecnológicos como tema e mesmo redes sociais ampliadas e mais robustas de escritores e editores do mundo inteiro são a mínima parte deste universo na cultura escrita.

Sobre aspectos particularmente tecnológicos, é interessante citar a impressão digital e sob demanda que altera, drasticamente, questões de tiragem, financeiras e de estocagem, assim como mudam elementos ligados à distribuição apenas digital de obras que alcançam públicos mais distantes a custo muito menor. O livro digital, no entanto, não parece ter reduzido a força do livro impresso, tendo-o, ao contrário, como uma alternativa e mesmo um aliado.

\section{Movimentos na leitura}

Os movimentos nas práticas da leitura talvez sejam, hoje, os mais estudados, em diversos campos, porque há interesses dispersos sobre a figura do leitor, ora tratado como estudante, ora como consumidor ou colaborador. Se antes das possibilidades editoriais trazidas pelas tecnologias digitais o leitor podia ser tratado como "passivo" ou o "receptor" de "conteúdos" transmitidos de maneira plena pelos enunciadores e seus veículos de comunicação, atualmente esse cenário vem sendo descrito e compreendido de outra maneira.

\footnotetext{
${ }^{17}$ Ver <www.estantevirtual.com.br>.

${ }^{18}$ Ver, por exemplo, <www.skoob.com.br>.

${ }^{19}$ Robert Darnton (2010) discute esse aspecto em sua obra.
} 
É comum que os estudos que têm como objeto ou que envolvem tecnologias digitais tenham passado a tratar o leitor como peça-chave das redes de produção editorial, até mesmo como coautor, considerando-se que ele possa interferir na obra que lê. Tal visão passa a considerar aspectos que vão da simples publicação de comentários à visibilidade que certos espaços virtuais de publicação têm tido na web. A leitura, então, é fundida (ou confundida) com a escrita, com a participação e com a autoria.

De outro ângulo, tem-se pensado a leitura em seus gestos, isto é, modos como o leitor usa dispositivos novos ou executa suas ações para ler, desde a compra dos textos (e-books, por exemplo) até sua apropriação física de um tablet, um smartphone ou um e-reader. Pegar, ligar, abrir, passar páginas, lidar com cliques e o hipertexto, manter-se ou abandonar a leitura. Gestos, em suma, mas gestos que estão ligados a habilidades cognitivas, também amplamente estudadas. Como ele navega e como ele compreende são questões que intrigam pesquisadores desde, pelo menos, os anos 1990.20

Quero retomar uma frase anterior em que afirmei que o leitor de novos dispositivos passa páginas. Nesse sentido, voltamos a questões de produção editorial, particularmente nas considerações sobre a dificuldade, ainda atual, de se produzir edições genuinamente digitais. Como em movimentações anteriores da cultura escrita, o que vemos são apropriações de modos e estéticas ainda ligados à cultura impressa. Chartier questiona isso (1998, p. 159), levantando uma pergunta importante: "Seria interessante aprofundar por que a metáfora da navegação textual se impôs em relação a este novo suporte do texto". Pois se antes falávamos em "virar páginas" ou em um "campo" (como lembra Certeau, 2004), na atualidade falamos em navegar, ação que não dispensa bússolas e outros modos de orientação. Para Chartier (1998, p. 159), há interesse em estudar "todas as metáforas utilizadas em relação a uma ou outra das formas de representação do texto, do rolo ao códice, do códice ao livro impresso e do livro impresso ao texto eletrônico".

Para Chartier (1998, p. 149), "a relação da leitura frente à tela suprime toda presença do objeto impresso nas mãos do leitor". A representação de

\footnotetext{
${ }^{20}$ Muitas teses foram escritas sobre isso e continuam sendo. Vou citar ao menos as minhas e as de Ana Elisa Novais, todas pela UFMG. Ribeiro (2003; 2008), Novais (2011). Coscarelli vem, atualmente, trabalhando nas questões de navegação e leitura, juntamente com Julie Coiro, nos Estados Unidos. Ver, para apenas uma entrada, Coiro (2011).
} 
texto na tela, que é apenas uma representação, tem, para o historiador, importância na maneira como lidamos com as obras e como nos movemos na cultura escrita. "Vemos de imediato uma forma de texto que muda em sua estrutura e em sua disposição. [...] Não acabamos de pensar os efeitos próprios e revolucionários deste novo tipo de representação textual". E até hoje, anos depois da afirmação do historiador, não temos certeza sobre tais mudanças, que ele chama de "revolucionárias".

Segundo Chartier (1998, p. 283):

Precisamos desconstruir os vários valores associados ao livro para entendermos isto: se considerarmos seu valor como suporte de informação, perceberemos que o texto subsiste no ciberespaço, apenas a página (como espaço de leitura e de escrita) transformase. Antes átomos (pedra, argila, papiro, pergaminho e papel), agora bits, fótons.

\section{Conclusões provisórias}

Impressiona a lucidez das afirmações dos historiadores do livro, mesmo há mais tempo, quando tudo o que dizia respeito aos livros e à tecnologia digital poderia, ainda, parecer concorrente. A conciliação já aparecia na proposta de Chartier (1998, p. 283) quando ele dizia que

faz-se necessário reconhecer que somos todos parceiros, relutantes ou entusiasmados, necessitando adquirir novas habilidades ("alfabetização" digital) para alcançar as mesmas antigas metas (comunicação, informação e conhecimento) e precisando também reavaliar constantemente nossos conceitos sobre tais assuntos. A influência do impresso é ainda tão forte que a maioria das metáforas usadas para descrever o novo suporte usa terminologia e imagens advindas deste momento tecnológico anterior. Semelhante ao que aconteceu com a relação à imprensa, são as novas gerações que conseguirão fazer um uso prático da tecnologia de modo verdadeiramente original, resolvendo também as dificuldades legais e financeiras que são ainda arrastadas do modelo impresso.

A "página", o "folhear", as "abas" de "arquivos" e outros elementos da cultura impressa mantêm-se firmes nas representações digitais, mas o contrário também já ocorreu há muito. Os links, certa diagramação 
característica e a navegação são elementos que passaram a constituir materialidades impressas em jornais, revistas e mesmo em livros. Os parceiros "relutantes" ou "entusiasmados" continuam suas discussões polarizadas, enquanto a produção editorial busca soluções tanto impressas quanto digitais para um leitor que ampliou suas formas de leitura e consumo.

As tríplices "revoluções" de Chartier, representadas na Figura 1, precisam, cada vez mais, ser compreendidas como uma rede de movimentos que se vão interinfluenciando (por isso a representação circular, interconectada), reconfigurando uma paisagem cultural, a da escrita, que ganha novos matizes, sem perder a força, inclusive - e principalmente - no campo da literatura.

\section{Referências}

ABREU, Márcia (Org.) (2000). Leitura, história e história da leitura. São Paulo: Mercado de Letras.

ALBARRAN, Alí A.; RIBEIRO, Ana Elisa (2013). As fronteiras do livro. In: CONGRESSO BRASILEIRO DE CIÊNCIAS DA COMUNICAÇÃO, 36., Manaus, 2013. Anais... Manaus: Intercom. p. 1-15.

BAHLOUL, Joëlle (2002). Lecturas precarias. Estudio sociológico sobre los "poco lectores". Tradução ao espanhol de Roberto Cue. Cidade do México: Fondo de Cultura Económica.

BARTHES, Roland (1984). A morte do autor. In: BARTHES, Roland. O rumor da lingua. Lisboa: Edições 70.

BELLEI, Sérgio (2005). Autores, leitores e a nova textualidade. In: ABREU, Márcia; SCHAPOCHNIK, Nelson (Org.). Cultura letrada no Brasil: objetos e práticas. Campinas: Mercado de Letras; Associação de Leitura do Brasil (ALB); São Paulo: Fapesp. (Coleção Histórias de Leitura).

CERTEAU, Michel de (2008). A invenção do cotidiano - Artes de fazer. 14. ed. Tradução de Ephraim Ferreira Alves. Petrópolis: Vozes.

CESNIK, Fábio (2015). Livro digital. In: FESTIVAL LITERÁRIO DE ARAXÁ FliAraxá, Araxá, 29 ago. Comunicação oral.

CHARTIER, Roger (1998). A ordem dos livros: leitores, autores e bibliotecas na Europa entre os séculos XIV e XVIII. 2. ed. Tradução de Mary Del Priore. Brasília: Editora Universidade de Brasília. 
CHARTIER, Roger (2001). Cultura escrita, literatura e história: conversas de Roger Chartier com Carlos Aguirre Anaya, Jesús Anaya Rosique, Daniel Goldin e Antônio Saborit. Porto Alegre: Artmed.

CHARTIER, Roger (2002). Os desafios da escrita. Tradução de Fulvia M. L. Moretto. São Paulo: Editora Unesp.

COIRO, Julie (2011). Predicting reading comprehension on the internet: contributions of offline reading skills, online reading skills, and prior knowledge, Journal of Literacy Research, 12 Out. Disponível em: <http://goo.gl/Vu9E7q>.

DARNTON, Robert (2010). A questão dos livros. Tradução de Daniel Pelizzari. São Paulo: Companhia das Letras.

FOUCAULT, Michel (2002). O que é um autor? Portugal: Veja/Passagens.

GUIMARÃES, Pablo de Araújo (2013). Uma tecnologia na mão e uma ideia na cabeça: pequenas editoras, autores independentes e as novas possibilidades de publicação de livros. Dissertação (Mestrado em Estudos de Linguagens) Centro Federal de Educação Tecnológica de Minas Gerais.

LAJOLO, Marisa; ZILBERMAN, Regina (2002). A leitura rarefeita. São Paulo: Ática.

MARTINS, Jorge (2005). Profissões do livro: editores e gráficos, críticos e livreiros. Lisboa: Verbo.

NOVAIS, Ana Elisa Costa (2008). Leitura nas interfaces gráficas de computador: compreendendo a gramática das interfaces. Dissertação (Mestrado em Estudos Linguísticos) - Universidade Federal de Minas Gerais, Belo Horizonte.

RIBEIRO, Ana Elisa (2003). Ler na tela. Dissertação (Mestrado em Estudos Linguísticos) - Faculdade de Letras da Universidade Federal de Minas Gerais, Belo Horizonte.

RIBEIRO, Ana Elisa (2008). Navegar lendo, ler navegando. Tese (Doutorado em Linguística Aplicada) - Faculdade de Letras da Universidade Federal de Minas Gerais, Belo Horizonte.

RIBEIRO, Ana Elisa (2009). Notas sobre o conceito de transposição e suas implicações para os estudos da leitura de jornais on-line. Em Questão, Porto Alegre, v. 15, p. 15/1-30.

RIBEIRO, Ana Elisa (2009a). Relações virtuais, edições de papel e a renovação da literatura brasileira. In: SEMINÁRIO BRASILEIRO LIVRO E HISTÓRIA EDITORIAL, 2., Rio de Janeiro/Niterói, 2009. Anais... Niterói: UFF. Disponível em: <http://goo.gl/8tmnwR>. Acesso em: 5 set. 2015. 
RIBEIRO, Ana Elisa (2011). The book is on the tablet: visadas no discurso sobre o livro digital na imprensa. In: CONGRESSO BRASILEIRO DE CIÊNCIAS DA COMUNICAÇÃO, 34., Recife, 2011. Anais... Recife: Unicap, p. 1-15.

RIBEIRO, Ana Elisa (2013). No Brasil, só se entende escrever em jornal - Clarice Lispector, Fernando Sabino e redes de edição no século XX. In: ENCONTRO NACIONAL DE HISTÓRIA DA MÍDIA, 9., Ouro Preto, 2013. Anais... Ouro Preto: Ufop Alcar.

RIBEIRO, Ana Elisa (2013a). Não tem que ser bom editor, tem que ser rápido: redes de edição de Clarice Lispector em meados do séc. XX. In: CONGRESSO BRASILEIRO DE CIÊNCIAS DA COMUNICAÇÃO, 35., Manaus, 2013. Anais do XXXVI Congresso Brasileiro de Ciências da Comunicação. Manaus: Intercom.

RIBEIRO, Ana Elisa. (2013b) Cultura escrita, cultura impressa e cultura digital: contiguidades e tensões. In: FIORENTINI, Leda Maria Rangearo et al. (Org.). Estilos de aprendizagem, tecnologias e inovações na educação. Brasília: Universidade de Brasília. p. 13-21.

RIBEIRO, Ana Elisa; GUIMARÃES, Pablo A. (2014) Livrarias-editoras em Belo Horizonte: cenário contemporâneo e perspectivas. In: CONGRESSO BRASILEIRO DE CIÊNCIAS DA COMUNICAÇÃO, 37., Foz do Iguaçu, 2014. Anais... São Paulo: Intercom. v. 1. p. 1-15.

RIBEIRO, Ana Elisa (2015). Redes de edição e redes sociais: cruzamentos e questões. No prelo.

SALGADO, Luciana S. (2011). Ritos genéticos editoriais: autoria e textualização. São Paulo: Fapesp; Annablume.

SALGADO, Luciana S. (2013). Ritos genéticos editoriais: uma abordagem discursiva da edição de textos. Revista do Instituto de Estudos Brasileiros, São Paulo, v. 1, p. 253-276.

SARAMAGO, José. (1989). História do cerco de Lisboa. São Paulo: Companhia das Letras.

VAN LEEUWEN, Theo (2004). Dez razões pelas quais os linguistas devem prestar atenção na comunicação visual. In: LEVINE, Philip; SCOLLON, Ron (Ed.). Discourse \& Technology: multimodal discourse analysis. Washington: Georgetown University Press. (tradução livre de Ana Elisa Ribeiro).

ZAID, Gabriel (2004). Livros demais! Sobre ler, escrever e publicar. Tradução de Felipe Lindoso. São Paulo: Summus.

Recebido em dezembro de 2014. Aprovado em junho de 2015. 


\section{resumo/abstract/resumen}

\section{Questões provisórias sobre literatura e tecnologia: um diálogo com Roger Chartier}

Ana Elisa Ribeiro

Este trabalho discute noções de leitura e tecnologia, em intenso diálogo com o historiador Roger Chartier. No Brasil, ele é considerado leitura obrigatória no campo da edição e das tecnologias do livro. Com base em uma bibliografia bastante relevante sobre o tema, são compiladas e discutidas algumas afirmações de Chartier sobre movimentos da cultura escrita com a chegada das tecnologias digitais, especialmente no que se relaciona à edição de livros e à literatura.

Palavras-chave: produção editorial, literatura, tecnologias digitais, Roger Chartier.

\section{Temporary questions on literature and technology: a dialogue with Roger Chartier}

\section{Ana Elisa Ribeiro}

This paper discusses reading and technology, in an intense dialogue with the works of famous French history researcher Roger Chartier. In Brazil, he is considered an obligatory reference in subjects like edition, publishing and technologies of books. Based on a relevant bibliography by Chartier, published in Portuguese, some of his ideas and concepts about writing culture, especially before digital technologies, are compiled and discussed here. Also, relations between books publishing and literature are linked and discussed.

Keywords: editorial production, literature, digital technologies, Roger Chartier.

\section{Literatura: contexto digital, hipercolonialismo y materialidades}

Ana Elisa Ribeiro

Chartier. En Brasil, el historiador es considerado lectura obligatoria en el campo de las tecnologías y da publicación de libros. Sobre la base de una literatura muy relevante sobre el tema, habemos compilado y analizado algunas afirmaciones de Chartier acerca de cómo se mueve la cultura escrita despues de la llegada de las tecnologías digitales, especialmente en lo que se refiere a la publicación de libros y a la literatura.

Palabras clave: producción editorial, literatura, tecnologías digitales, Roger Chartier. 